Original Article

\title{
MORPHOMETRIC ANALYSIS OF FORAMEN M AGNUM FOR SEX DETERMINATION IN SOUTH INDIAN POPULATION
}

\author{
Radhakrishna S.K. ${ }^{1}$, Shivarama C.H. ${ }^{2}$, Ramakrishna A. ${ }^{3}$, Bhagya B. ${ }^{4}$ \\ ${ }^{1}$ Asst. Professor, ${ }^{2}$ Postgraduate Student, ${ }^{3}$ Professor \& Head, ${ }^{4}$ Lecturer, \\ Department of Anatomy, Yenepoya M edical College, Yenepoya University, Mangalore - 575 018, India \\ Correspondence: \\ Bhagya B., \\ Phone : 0824 2204668/69 E-mail : bagyabs@gmail.com
}

\begin{abstract}
:
In this study the foramen magnum was analyzed for sex differences using standard osteometric techniques.

We analyzed 100 (55 males and 45 females) skulls from the department of Anatomy, Yenepoya M edical College which were in good condition with a record of sex. The cranial base was visually assessed for foramen magnum shape. M orphometry (anteroposterior diameter (APD) \& Transverse diameter (TD)) was determined and their differences by gender $(p<0.05)$ were ascertained.

Oval shape was the most common followed by round, tetragonal and pentagonal in both sex. The results demonstrated that sexual dimorphism is present in the foramen magnum. APD and TD were higher in male skulls than females (34.04 vs 31.72 and 28.63 vs 26.59).

In incomplete skeletons, metric analysis of the foramen magnum may provide a statistically useful indication as to sex of the unknown skull.
\end{abstract}

Keywords : foramen magnum, shape, anterioposterior diameter, transverse diameter, sexual dimorphism

\section{Introduction :}

Sex determination from skull morphology is important in medico-legal cases. In most of the forensic studies the skeleton will be incomplete and makes gender identification difficult. The foramen magnum (FM) is one of the primary centers of ossification on the cranial base during growth and development, and is located inferior to the sagittal suture, on the cranial base. Characteristics of FM and cranial base have identifying features for sexing ${ }^{1-3}$. $M$ any authors have reported the usefulness of the FM in gender determination ${ }^{4 \cdot 9}$. Significant craniometry differences exist in the FM between the two sexes within a restricted geographical region and historical period ${ }^{10 .}$. Gunay \& Altinkok ${ }^{13}$ reported that the dimensions of the FM were useful in sex determination but the total area was not a good indicator. The FM measurements in males are greater because they tend to have larger heads than females ${ }^{14}$. Uysal ${ }^{15}$ using Computed Tomography scans of living individuals reported all dimensions of FM were larger in males than females, with the length and width of the right occipital condyle and the width of the FM reflecting the greatest differences. M urshed ${ }^{14}$ classified FM into eight different shapes: oval, egg, round, tetragonal, pentagonal, hexagonal, irregular A, and irregular B. Updating temporal changes of skull morphometry is essential for forensic study and anthropologists. Hence, the focus of this research was to evaluate the morphological differences of foramen magnum for sex determination in human skulls of South India.

\section{Materials and methods:}

100 skulls ( 55 males and 45 females), from the Department of Anatomy, Yenepoya Medical College, Yenepoya University were used for the study. Only skulls with good conditions with gender identified in book record were included for the study. The skull samples which were damaged, incomplete or without identification were not included in the study. All the 102 cranial bases were visually assessed for foramen magnum shape classification. Each foramen magnum was classified into one of the four shapes, oval, round, tetragonal, pentagonal (Fig 1)

Morphometry (Anterioposterior diameter (APD) \& Transverse diameter (TD)) of the foramen magnum was measured using Vernier Caliper (Forbes) to an accuracy of $0.5 \mathrm{~mm}$. APD of the foramen magnum is the distance between opisthion to basion along the midsagittal plane ${ }^{16}$ 
(Fig 2), while TD is the maximum distance along the transverse plane. (Fig 2) Differences in length and width of foramen magnum between males and females were assessed byt-test ${ }^{17}$.

\section{Results :}

Table 1 details the number of skulls in various shapes. Oval shape was the most common followed by round, tetragonal and pentagonal in both males and females. The dimensions of the foramen magnum for 100 skulls showed statistically significant differences. The APD (34.04 vs 31.72 ) and TD (28.63 vs 26.59) were significantly higher in malesthan in females $(P \varangle 0.05)$ (Table 2) (Fig 3).

Table 1: Foramen magnum shape categories

\begin{tabular}{|l|c|c|c|c|}
\hline & Oval & Round & Tetragonal & Pentagonal \\
\hline Male & 22 & 16 & 10 & 8 \\
\hline Female & 17 & 12 & 9 & 6 \\
\hline Total & 39 & 28 & 19 & 14 \\
\hline
\end{tabular}

Fig 1: Shapes of foramen magnum

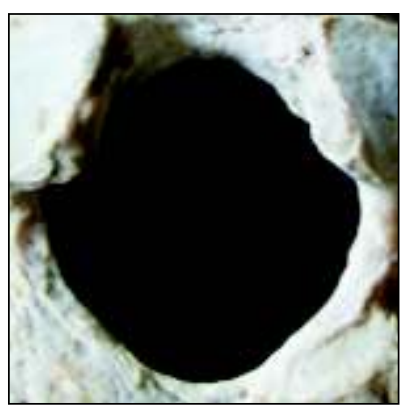

Oval

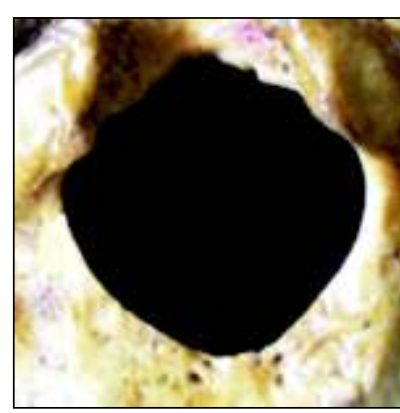

Tetragonal
Fig 2: Anterioposterior diameter (APD) and Transverse diameter (TD)

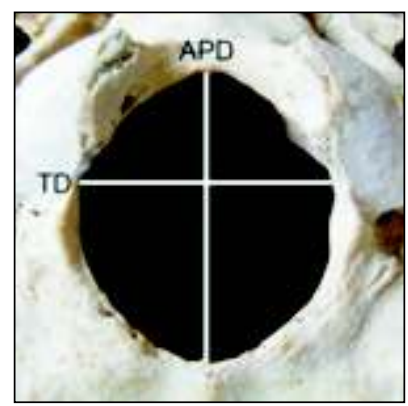

\section{Discussion :}

The sex determination of incomplete or damaged skeletons is an important task in forensic medicine. Anthropometric measurements can aid in solving such problems of gender identification. The foramen magnum was used since it is a regular structure and less likely to major morphological changes. The morphometry of the skull can be used for assessing sexual dimorphism has been reported by Gunay ${ }^{13}$, Westcott and Moore-Jansen ${ }^{18}$ and Murshed et. al., ${ }^{14}$. The comparison of the morphometric analysis obtained in this study with the results of other studies had the following results: the length (APD) of the foramen magnum of South Indian male skulls (34.04 \pm 2.36 )

Table 2: Anterioposterior diameter (APD) (mm) and Transverse diameter (TD) $(\mathrm{mm})$ of the foramen magnum correlated with gender $(\mathrm{mm})$. (mean $\pm \mathrm{SD})$

\begin{tabular}{|l|l|l|}
\hline Gender & APD & TD \\
\hline$M$ ale $n=55$ & $34.04 \pm 2.36$ & $28.63 \pm 1.89$ \\
\hline Female $n=45$ & $31.72 \pm 2.14$ & $26.59 \pm 1.64$ \\
\hline \multicolumn{2}{|l|}{ Correlation is significant at $p \varangle 0.05$} \\
\hline
\end{tabular}

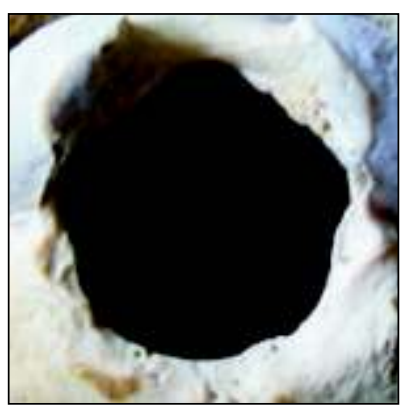

Pentagonal

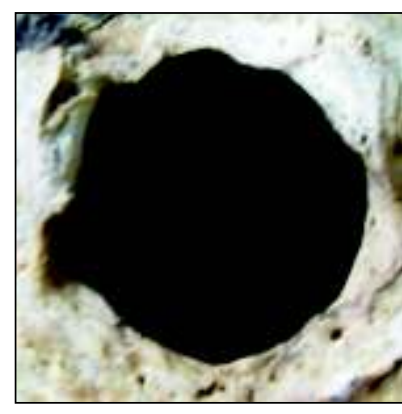

Round
Fig: 3 M orphometry of foramen magnum correlated with gender

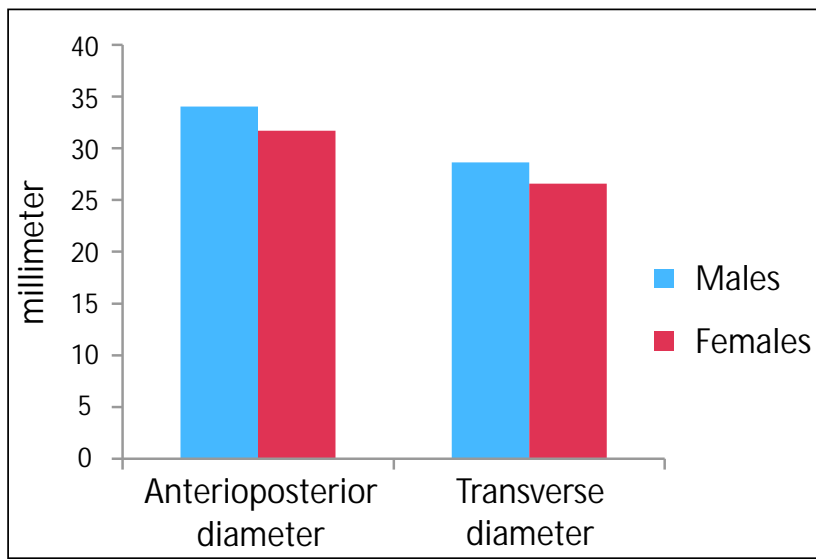


was lower than the Brazilian male skulls $(35.7 \pm 0.29)^{7}$ the Turkish $(37.2 \pm 3.43)^{14}$, Spanish $(36.2 \pm 0.3)^{19}$, English populations $(35.91 \pm 2.41)^{20}$, and the Indian population $(35.5 \pm 2.8)^{21}$. Similarly APD of the female skulls of the South Indian population was $(31.72 \pm 2.14)$ lower than Brazilian population $(35.1 \pm 0.33)^{7}$, than those of the Turkish (34.6 \pm 3.16) $)^{14}$, Spanish $(34.30 \pm 0)^{19}$, Indian $(32.0 \pm 2.8)^{21}$, and English populations $(34.71 \pm 1.91)^{20}$. Regarding the width (TD) of the foramen magnum, the values of the South Indian male skulls (28.63 \pm 1.89$)$ was lower than Brazilian male skulls $(30.3 \pm 0.20)^{7}$, Indians $(29.6 \pm 1.9)^{21}$, the Turkish $(31.6 \pm 2.99)^{14}$, Spanish $(31.1 \pm 0.3)^{19}$, and English populations $(30.51 \pm 1.77)^{20}$. The same measure for the

\section{References :}

1. Holland TD. Race Determination of Fragmentary Crania by Analysis of the Cranial Base. Journal of Forensic Sciences1986a; 31(2):719-725.

2. Holland TD. Sex Determination of Fragmentary Crania by Analysis of the Cranial Base. American Journal of Physical Anthropology1986b; 70(2):203-208.

3. Holland TD. Use of the Cranial Base in the Identification of Fire Victims. Journal of Forensic Sciences1989; 34(2): 458-460.

4. Ferreira FV, Rosenberg B, da Luz HP. The Foramen Magnum index in Brazilians. Rev. Fac. Odontol. Sao Paulo, 1967; 5(4): 297-302.

5. Teixeira WRG. Sex identification utilizing the size of the foramen magnum. American Journal of Forensic M edicine and Pathology.1982; 3: 203-206.

6. Zadvornovlu N. Variations in the shape of the foramen magnum and the structure of its posterior border. Arkh. Anat. Gistol. Embriol., 1972; 63(7): 42-50.

7. Manoel C, Prado FB, Caria PHF, Groppo FC. Morphometric analysis of the foramen magnum in human skulls of brazilian individuals: its relation to gender. Braz. J. M orphol. Sci 2009; 26(2): 104-108.

8. Ukoha U, Egwu OA, Okafor IJ, Anyabolu AE, Ndukwe GU, Okpala I. International Journal of Biological Medical Research. 2011; 2(4): 878881.

9. Suazo GIC, Russo PP, Zavando MDA, Smith RL, Sexual dimorphism in foramen magnum dimensions. International Journal of M orphology; 2009; 27(1): 21-23.

10. Joy O, Ahmed E, Gabriel O, Ezon-ebidor E. Anthropometric study of the facial and nasal length of adult Igbo ethnic group in Nigeria. Internet J Biol Anthropol 2009; 2(2).

11. Zaidi SH, Dayal SS. Variations in the shape of foramen magnum in Indian skulls. AnatAnz Jena 1988; 167: 338-40. female skulls of the South Indian population $(26.59 \pm 1.64)$ was lower than the Brazilian population $(29.4 \pm 0.23)^{7}$ Indian $(27.1 \pm 1.6)^{21}$ and Turkish populations $(29.3 \pm 2.19)^{14}$ and lower than Spanish $(29.6 \pm 0.3)^{19}$ and English populations $(29.36 \pm 1.96)^{20}$. The results demonstrated that sexual dimorphism is present in the foramen magnum. In incomplete skeletons, metric analysis of the foramen magnum may provide a statistically useful indication as to sex of the unknown skull.

\section{Acknowledgements :}

The authors are grateful to Yenepoya University for permission to carry out thisstudy.

12. Henriquez-Pino J, Cricenti SV, Didio LJA. Morfometria del foramen magno y surelación con el tipo de cráneo en individuosbrasileños. Rev. Chil. Anat.1995; 13(2): 159-64.

13. Günay $Y$, Altinkök $M$. The value of the size of foramen magnum in sex determination. Journal of Clinical Forensic Medicine. 2000; 7: 147149.

14. M urshed KA, Çiçekçibasi AE, Tuncer I. M orphometric Evaluation of the Foramen Magnum and Variations in its Shape: A Study on Computerized Tomographic Images of Normal Adults.Turkish Journal of Medical Sciences. 2003; 33(1): 301-306.

15. Uysal S, Gokharman D, Kascar M, Tuncbilek I, Kosar U. Estimation of Sex by 3D CT Measurements of the Foramen Magnum. Journal of Forensic Sciences 2003; 50(6): 1-5.

16. White TD. Human Osteology, second edition, 2000, Academic Press, San Diego.

17. Statsoft Inc 1995 STATISTICA for windows. Tulsa, Okla., USA.

18. Westcott D. and Moore-jansen P. Metric variation in the human occipital bone: forensic anthropological applications. Journal Forensic Science.2001; 5(46): 1159-1163.

19. Herrera CIC. Study of the anatomic metric values of the foramen magnum and its relation to sex. Acta Anatomica. 1987; 130: 344-347.

20. Gapert R, Black S, Last J. Sex determination from the foramen magnum: discriminant function analysis in an eighteenth and nineteenth century British sample. International Journal of Legal Medicine. 2008; 123(1): 25-33.

21. Routal RR, Pal GP, Bhagwat SS. Metrical studies with sexual dimorphism in foramen magnum of human crania. Journal of the Anatomical Society of India. 1984; 2(33): 85-89. 